\title{
CORRELATION BETWEEN MOTOR ABILITIES OF ELITE FEMALE FOOTBALL PLAYERS
}

\author{
Petar Peev, Marin Gadev \\ National Sports Academy "Vassil Levski"
}

\begin{abstract}
ASTRACT
Focus of this research is the relationship between the motor abilities. The interest in this topic is dictated from the fact that there isn't enough information about it in elite female football. For the purpose of the research we made tests to define the level of development of the motor abilities of 68 elite female football players. We also made a descriptive statistics and correlation analysis and we received the following results: descriptive statistics shows that the researched indicators are highly homogeneous (in range of $V \%=2,67$ to 5,05); the correlation between accelerative abilities and maximal sprinting abilities is moderate and positive $(r=0,634)$; the correlation between power abilities with explosive character and other researched abilities is moderate and negative ( $r=-0,430, r=-0,494, r=-0,455)$; the speed endurance abilities have moderate to strong and positive correlation with the accelerative and maximal sprinting abilities ( $r=0,600, r=0,809)$. Conclusions: 1) Improving the power abilities with explosive character creates beneficial conditions in development of the other motor abilities; 2) Improving of the speed abilities is a major component of the conditioning in female soccer; 3) The most important factor for improving the speed endurance is creating a "speed reserve".
\end{abstract}

Key words: women, football, elite, conditioning, correlation

\section{INTRODUCTION}

The main characteristic that defines the football game for both sexes is its intermittent character of the match-play and training process. The data about the motor activity in female football shows some similarities with male football but only in relative values (Mohr et al., 2008; Datson, 2014). Systematic review of the literature shows the authors' interest in disclosing the question about relationship of the motor abilities of male and youth football (Chamariet al., 2004; Stølenet al., 2005; Kirkendall, 2007; Mujikaet al., 2009; Martinez-Lagunas et al., 2014; Rajkumar, 2015; Datsonet al., 2017; Milanovićet al., 2017, Peev, 2017). However, we cannot observe the same interest in female football (Mujikaet al., 2009, McCurdyet al, 2010). We can even say that the data about their re- lationship in football is scarce. From theoretical point of view, the knowledge about the relationship between motor abilities is an important part of the conditioning and their correlation can optimize the training process (Polmanet al, 2004; Mansonet al., 2014). That knowledge is a precondition for structuring and defining an algorithm for methodical development of motor abilities in conditioning. This knowledge about transfer and transformation of motor ability and their critical values takes main place in the methodology but it is not so deeply researched. As we know all of the researched motor abilities are connected and dependable on each other. That is the reason to research their connections but sometimes the over increase of the values of one of the abilities can affect the others in negative ways. If we find exact 
model of development of the motor abilities, we can boost the training process and optimize the conditioning. All these statements are well discussed in Gadev's (2013) thesis about conditioning in football.

In order to optimize the conditioning of the women football we defined the purpose of the present study as: Disclosing the relationship between main motor abilities of elite female football players.

When we accomplished our goal, we solved the following tasks:

Research of the variability of the indi- cators that characterizes speed, power and speed endurance motor abilities;

Determination of the structural relationship between the researched motor abilities.

\section{METHODS}

Description of the methods

To solve the tasks of the research we used the following methods - testing, optometry, chronometry, statistical analysis (descriptive and correlative analysis). The tests that characterize the motor abilities and their forms of presence are in table №1.

Table 1. Tests that characterize the motor abilities and their forms of performance

\begin{tabular}{cccc}
\hline $\begin{array}{c}\text { Number of } \\
\text { test }\end{array}$ & Name of the test & $\begin{array}{c}\text { Measurement } \\
\text { units }\end{array}$ & Precision \\
\hline 1. & 20 m running form standing start & $\mathrm{sec}$ & 0,01 \\
\hline 2. & 20 m running with flying start & $\mathrm{sec}$ & 0,01 \\
\hline 3. & Standing triple jump & $\mathrm{m}$ & 0,01 \\
\hline 4. & $3 \times 50 \mathrm{~m}$ shuttle run from standing start & $\mathrm{sec}$ & 0,01 \\
\hline
\end{tabular}

When we researched the speed abilities, and their two forms of presence, we used the following tests: $20 \mathrm{~m}$ running from standing start (20 m s.s.) for accelerative abilities and $20 \mathrm{~m}$ running from flying start (20 $\mathrm{m}$ f.s.) for maximal sprinting ability. The test $20 \mathrm{~m}$ f.s. we made with 10 meters approach before the first photocell. The test is in agreement of the research of Benton (2000) Young et.al. (2008,) Turner et.al. (2011) and Kutlu et. al. (2017) about the optimal distance for optimal sprinting distance for defining the maximal springing abilities. The track was measured with manual tape and marked with two cone and photocell on the start line and the final line. All the players start when they are ready and confident from a line, 30 centimeters be- hind the first photocell. The procedures of the test are done by standard methodology for this type of research with electronic timing system (Newtest Oy, Finland). We used these tests because the average sprint distance in team sports is between 15 and 21 meters (Gabbett, 2012; Andrzejewski, et. al., 2013 and 2015). Also, they are commonly used, and their validity and reliability are widely researched. The research done by Haugen et. al. $(2012,2013)$ showed that the real difference of sprint abilities could be found in 20 meters section.

We researched the level of power abilities with explosive character with the test standing triple jump (TJ). The tested subjects do 3 consequent jumps from standing posi- 
tion with two legs on the ground. The athlete starts like she will do a standing long jump. The first phase is a hop from a stand still behind a starting line, which requires the athlete to take-off from a two-footed stand, split in midair, and land on the convenient foot (depends on the strength of the legs and the preference of the athlete). The next phase is a long-stretched step, and the athlete lands on the opposite foot. The last phase is the jump, where the athlete lands on both feet. There are two combinations of execution of this test: two legs, the right or left foot then left or right foot then landing on two legs on the ground. The distance of the jump is measured with manual tape on the closest mark toward the starting line (usually on the heels). Every subject of research makes two jumps. The best trial is taken into account. Usually for defining the level of development of the power abilities with explosive character research- ers use counter movement jump (Haugen et. al. 2012) but we think that we can use the jump test in horizontal plane because there is high correlation in the two types of jumps and it is closer to the running locomotion (Rohr, 1992).

We measured the level of development of the speed endurance with $3 \times 50 \mathrm{~m}$ shuttle run from standing start $(3 \times 50)$, that was used before by Gadev $(2013,2014)$ and Peev et al. (2017). The test was validated before by Peev (2017) with 14 years old football players. The test is performed on a track with length of $50 \mathrm{~m}$ that is marked with two cones. The requirement for all the subject is to pass the distance with two turns for shorter time. The time (speed) is measured with electronic stopwatch, Model - HS-80TW-1DF (Casio Computer Co, LTD, Shibuya, Tokyo, Japan). We can see the performance of the test in figure 1.

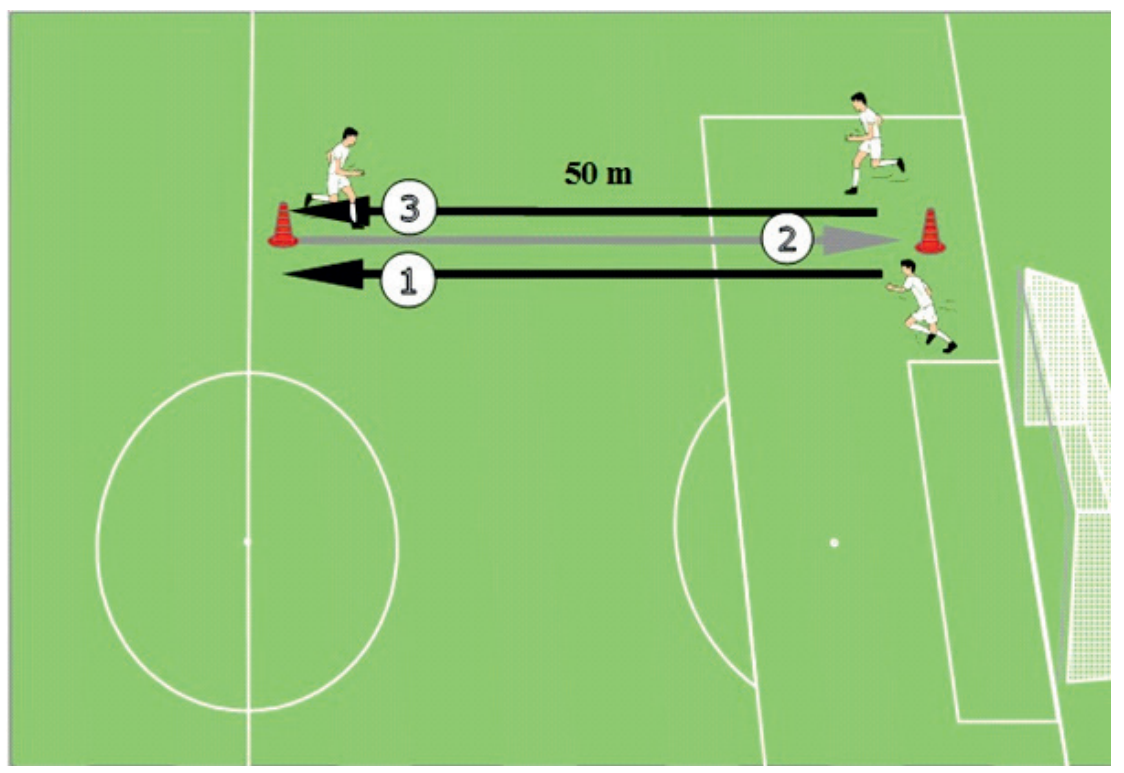

Figure 1. How to perform the test $3 \times 50 \mathrm{~m}$ shuttle run from standing position

All tests were held in one day, three times a year as part of the control of the physical performance of the players. Our experimental approach was the following:

1. All of the testing procedures were made on a football field with natural grass.
2. Warm up that consisted of 8 minutes of running; 6 minutes of exercises for whole body; 6 minutes of stretching, 3 accelerations of $20 \mathrm{~m}$.

3. First, we held the standing triple jump. All the participant made 2 consequent jumps 
with 1 minute between them.

4. After 12 minutes we made the two sprinting tests $(20 \mathrm{~m}$ running from standing start and $20 \mathrm{~m}$ running with flying start). We made two attempts for each with 6-8 minutes' recovery between them). The best attempt was taken into account. All of the participant ran alone.

5. After 15 minutes of active recovery with stretching exercises we held the $3 \times 50 \mathrm{~m}$ shuttle run test. We made one attempt on the test. All of the participant ran two by two.

All statistical analyses were processed by SPSS Statistics 19 (Chicago, Illinois, IBM, USA). The research was done among 68 elite women football players from WFC "Rossiyanka“, Russia.

\section{RESULTS}

The data from the test and the descriptive statistics are presented in table 2 . The average result for $20 \mathrm{~m}$ s.s. is 3,17 seconds with maximal value of 3,39 and minimal of 2,91 seconds. The average time for $20 \mathrm{~m}$ f.s. is 2,77 seconds with maximal value of 3,12 and minimal of 2,51 seconds. The average result for TJ are 6,45 meters with individual values between 4,49 and 7,71 meters. The average time for $3 \times 50$ is 25,44 seconds with maximal value of 27,10 and minimal of 23,97 seconds. It is visible that all the research indicators are homogenous with coefficient of variation (V\%) between 2,67 to $5,05 \%$. This fact gives us a prediction for correct results and allows us to make a correlative analysis.

Table 2. Variability of indicator that characterizes motor abilities of women football players

\begin{tabular}{ccccc}
\hline $\begin{array}{c}\text { Statistical } \\
\text { indicator }\end{array}$ & $\begin{array}{c}\text { 20 m running } \\
\text { form standing } \\
\text { start }\end{array}$ & $\begin{array}{c}\text { 20 m running } \\
\text { with flying start }\end{array}$ & $\begin{array}{c}\text { Standing triple } \\
\text { jump }\end{array}$ & $\begin{array}{c}\text { 3x50 m shut- } \\
\text { tle run from } \\
\text { standing start }\end{array}$ \\
\cline { 2 - 5 } (seconds) & (seconds) & (centimeters) & (seconds) \\
\hline $\mathrm{X}$ & 3,17 & 2,77 & 6,45 & 25,44 \\
\hline $\mathrm{m}_{\mathrm{x}}$ & 0,01 & 0,02 & 0,04 & 0,08 \\
\hline $\mathrm{Me}$ & 3,19 & 2,76 & 6,38 & 25,37 \\
\hline $\mathrm{Mo}$ & 3,20 & 2,66 & 6,20 & 25,76 \\
\hline $\mathrm{S}$ & 0,11 & 0,14 & 0,29 & 0,68 \\
\hline $\mathrm{As}$ & $-0,04$ & 0,37 & 0,64 & 0,24 \\
\hline $\mathrm{Ex}$ & $-0,27$ & $-0,29$ & $-0,34$ & $-0,22$ \\
\hline $\mathrm{R}$ & 0,48 & 0,61 & 1,15 & 3,13 \\
\hline $\mathrm{X} \mathrm{min}$ & 2,91 & 2,51 & 5,95 & 23,97 \\
\hline $\mathrm{X} \mathrm{max}$ & 3,39 & 3,12 & 7,10 & 27,10 \\
\hline $\mathrm{V} \%$ & 3,47 & 5,05 & 4,49 & 2,67 \\
\hline
\end{tabular}

On the base of the data from the descriptive statistics, we disclose correlative interrelation between the researched motor abilities. Their values are presented in Table 3.

The correlation between accelerative abilities and maximal sprinting abilities is moderate and positive $(\mathrm{r}=0,634)$; the correlation between power abilities with explosive character and other researched abilities are moderate by strength and negative by direction as it follows speed endurance abilities ( $r=-0,430)$, maximal sprinting abilities $(\mathrm{r}=-0,494)$ and accelerative abilities $(r=-0,455)$. The speed endurance abilities have moderate to strong and positive correlation with the accelerative and maximal sprinting abilities $(r=0,600 ; r=0,809)$. 
Table 3. Correlative matrix of the correlation between motor abilities

\begin{tabular}{|c|c|c|c|c|}
\hline Tests $\sqrt{b} \Rightarrow$ & \multirow{2}{*}{$\begin{array}{c}20 \text { m standing } \\
\text { start }\end{array}$} & \multirow{3}{*}{$20 \mathrm{~m}$ flying start } & \multirow{4}{*}{ Triple jump } & \multirow{5}{*}{$\begin{array}{c}3 \times 50 \text { m } \\
\text { shuttle run }\end{array}$} \\
\hline $\begin{array}{c}20 \text { m standing } \\
\text { start }\end{array}$ & & & & \\
\hline 20 m flying start & $0,634^{*}$ & & & \\
\hline Triple jump & $-0,455^{*}$ & $-0,494^{*}$ & & \\
\hline $3 \times 50$ m shuttle run & $0,600^{* *}$ & $0,809^{* *}$ & $-0,430^{*}$ & \\
\hline
\end{tabular}

*Significance at 0,05 level, **Significance at 0,01 level

\section{DISCUSSION}

The data that is presented in tables 2 and 3 are an objective chance to analyze concrete relationship between the indicators that characterize speed endurance abilities with speed and power abilities. From theoretical point of view, there is no doubt that we must define the relationship between one of the most important ability in football, speed endurance abilities and the ones mentioned above.

We can observe from table 3 that the two forms of speed abilities greatly influence the performance of speed endurance $(\mathrm{r}=0,600$ and $r=0,809)$ with positive correlation. The strength of the correlation of accelerative abilities and the speed endurance abilities is moderate $(r=0,600)$. Meanwhile the correlation between speed endurance abilities and maximal sprinting abilities is with strong significance $(\mathrm{r}=0,809)$. This fact means that improving the speed abilities is a precondition to improve the speed endurance. In conclusion we can say that the level of development of the speed endurance to the greatest extent depends on the development of the different forms of speed abilities and most of all on the maximal sprinting abilities and creating a "speed reserve".

We found moderate and positive correlation between maximal sprinting abilities and accelerative abilities $(\mathrm{r}=0,634)$. The improvement of one of them leads to the improvement of the other. That relationship is not surprising because the two form of speed abilities are connected and dependable on anaerobic energy supply system (Turner et.al. 2011). This fact is in unison with the conception of Gadev (1997) and Vescovi and McGuigan (2008). Of course, this is not the only way of improving the result in the test. Other important component of sprint running is its technique of execution.

Another field of interest for sports practice is the correlation between speed and power abilities. As we can notice from table 3, the correlation between power abilities and accelerative and maximal sprinting abilities is negative and moderate by strength $(\mathrm{r}=-0,455$ and $r=-0,494)$. In other words, the speed abilities are moderately affected of the power abilities. This correlation is surprisingly low for us because the power is a main component in running and affects the ability to apply force on the ground. As a consequence of this when athletes can generate more power it is normal for them to sprint faster (improve the time in the tests). That is in unison with the results and statement of Peev (2017) and Bachvarovet.al. (2008). Other researchers found that this relationship was moderate to strong, but they used jumps in the vertical plain. According to McCurdy et al. (2010) this fact can be a consequence of the lower validity of the jump in the 
horizontal plane and sprint running, because of the specific technique that is required. The moderate correlation that is discovered in the present study between speed and power abilities is lower than the correlation that authors found in male football (Peev, 2017). In our opinion, the lack of higher correlation between power abilities of elite women football players with other types of motor abilities is due to the difference of the power characteristics of the two sexes. Another reason may be the technique of the power test. This conclusion is confirmed by Mujikaet al. (2009), Kirkendalland O'Malley (2002). In conclusion, we should use tests in vertical plane which are with better validity in football.

Interesting for the theory of the sport science is the issue of the influence of the power abilities on the speed endurance abilities. We can see in table 3 that the coefficient of correlation between speed endurance and power abilities with explosive character is moderate and negative $(\mathrm{r}=-0,430)$. That means that the bigger values of power abilities will cooperate with weak effect for improving the level of speed endurance. When we increase the result in tests that characterizes the power abilities with explosive character this influences indirectly the speed endurance and improves the speed abilities (Peev, 2014).

\section{CONCLUSIONS}

The data from the research give us a ground to make the following conclusions and recommendations about development of the motor abilities of elite women football players:

Improving the power abilities with explosive character creates beneficial conditions in development of the other motor abilities;

Improving of the speed abilities is a major component of the conditioning in female soccer;

The most important factor for improving the speed endurance is creating a "speed reserve".

\section{REFERENCES}

Andrzejewski, M., Chmura, J., Pluta, B., and Konarski, J. M. (2015). Sprinting Activities and Distance Covered by Top Level Europa League Soccer Players. International Journal of Sports Science and Coaching, Vol. 10, No.1, pp. 39-50.

Andrzejewski, M., Chmura, J., Pluta, B., Strzelczyk, R., and Kasprzak, A. (2013). Analysis of sprinting activities of professional soccer players, The Journal of Strength \& Conditioning Research, Vol. 27, No.8, pp. 2134-2140.

Bachvarov, M., Dimirov, L. and Gigov, A. (2008). Futbol: Presa, kondiciq, natisk: Kratka teoriq i mnogo uprajneniq, NSA- Press, Sofia, pp.120 // Бъчваров, М., Л. Димитров и А. Гигов (2008). Футбол: Преса, кондиция, натиск: Кратка теория и много упражнения, НСА-Прес, София, с. 120.;

Bangsbo, J., Mohr, M. Krustrup, P. (2006). Physical and metabolic demands of training and match-play in elite football players, Journal of Sports Sciences, Copenhagen, July 2006; Vol. 24, No. 7, pp. $665-674$.

Benton, D., (2000). An analysis of sprint running patterns in Australian Rules football: the effect of different starting velocities on the velocity profile (Doctoral dissertation, University of Ballarat) pp. 270.

Chamari, K., Hachana, Y., Ahmed, Y. B., Galy, O., Sghai“er, F. Chatard, J-C, Hue, O. and Wisløff, U. (2004). Field and laboratory testing in young elite soccer players, British Journal of Sports Medicine, No. 38, pp. 191196.

Datson, N., Hulton, A., Andersson, H., Lewis, T., Weston, M., Drust, B. and Gregson, W. (2014). Applied physiology of female soccer: An update, Sports Medicine, September, Vol. 44 No. 9, pp. 1225-1240.

Datson, N., Drust, B. Weston, M. Jarman, I.H., Lisboa, P.J. and Gregson, W. (2017). Match physical performance of elite female soccer players during international compe- 
tition, Journal of Strength and Conditioning Research, September, Vol. 31, No. 9, pp. 2379-2387.

Gabbett, T. J. (2012). Sprinting patterns of national rugby league competition, The Journal of Strength \& Conditioning Research, Vol. 26, No.1, pp. 121-130.

Gadev, M. (1997). Maksimalnata skorost kato factor v sprinta, Sofia, NSA- IPB, pp 76 // Гъдев, М., (1997). Максималната скорост като фактор в спринта, София., НСА-ИПБ, c. 76 .

Gadev, M. (2013). Teoretichni osnovi I metodiko-tehnologichni aspekti na nespecifichnata kondicionna podogtovka $\mathrm{v}$ detskounoshestkiq futbol, Sofia, $\mathrm{PhD}$ thesis, pp.301 // Гъдев, M., (2013). Теоретични основи и методико-технологични аспекти на неспецифична кондиционна подготовка в детско-юношеския футбол, София, Докторат, с. 311.

Gadev, M. (2014). Izsledvane na vzaimovruzkite na specialnata izdrujlivost sys skorostnite i skorostno-silovite dvigatelni sposobnosti $\mathrm{v}$ detsko-unoshestkiq futbol, “Sport i nauka", No.5, pp. 36-41 // Гъдев, М., (2014). Изследване на взаимовръзките на специалната издръжливост със скоростните и скоростно-силови двигателни способности в детско-юношеския футбол, „Спорт и наука”, (5): 36-41.

Haugen, T.A., Tønnessen, E. and Seiler, S., (2012). Speed and countermovement-jump characteristics of elite female soccer players, 1995-2010, International Journal of Sports Physiology and Performance, Vol. 7 No. 4, pp. 340-349.

Haugen, T.A., Tønnessen, E. and Seiler, S., (2013). Anaerobic performance testing of professional soccer players 1995-2010, International Journal of Sports Physiology and Performance, Vol. 8 No.2, pp. 148-156.

Kirkendall, D.T. (2007). Issues in training the female player, British Journal of Sports Medicine, August; Vol. 41 (Suppl I), pp. i64- $i 67$.

Kirkendall, T.and O'Malley, H. (2002). Field assessment of fitness for soccer: a study of highly skilled youth and national team members, Revista de Fútbol y Ciencia, Vol. 1 No. 1, pp. 21-28.

Kutlu, M., Yapici, H. and Yilmaz, A., (2017), Reliability and validity of a new test of agility and skill for female amateur soccer players, Journal of Human Kinetics, Vol.56 No.1, pp. 219-227.

Manson, S.A., Brughelli, M. and Harris, N.K. (2014). Physiological characteristics of international female soccer players, Journal of Strength and Conditioning Research, February, Vol. 28, No.2, pp. 308-318.

Martinez-Lagunas, V., Niessen, M. and Hartmann, U. (2014). Women's football: Player characteristics and demands of the game, Journal of Sport and Health Science, Vol.3, No.4, pp. 258-272.

McCurdy, K.W., Walker, J.L., Langford, G.A., Kutz, M.R., Guerrero, J.M. and McMillan, J. (2010). The relationship between kinematic determinants of jump and sprint performance in division I women soccer players, Journal of Strength and Conditioning Research, December, Vol. 24, No.12, pp. 32003208.

Milanović, Z., Sporiš, G., James, N., Trajković, N., Ignjatović, A., Sarmento, H., Trecroci, A. and Miguel Borges Mendes, B. (2017). Physiological Demands, Morphological Characteristics, Physical Abilities and Injuries of Female Soccer Players, Journal of Human Kinetics, December, Vol. 60, No.1, pp. 77-83.

Mohr, M., Krustrup, P., Andersson, H., Kirkendal, D. and Bangsbo, J. (2008). Match activities of elite women soccer players at different performance levels, Journal of Strength and Conditioning Research, March, Vol. 22, No.2, pp. 341-349.

Mujika, I., Santisteban, J., Impellizzeri, F. M. and Castagna, C. (2009). Fitness determi- 
nants of success in men's and women's football, Journal of Sports Sciences, January 15th, Vol. 27, No.2, pp. 107-114.

Peev, P. (2014). Interrelation between speed abilities and speed strength abilities and speed endurance of 13-14 years football players, 9th FIEP European Congress and 7th International Scientific Congress ,Sport, Stress, Adaptation" (congress proceesings), Sofia 9-12 October, pp. 1007.

Peev, P. (2017). Metodicheski podhodi za vuzdeistvie varhu skorostnata izdrajlivost pri 13-14 godishni futbolisti, Sofia, $\mathrm{PhD}$ thesis, pp.167 // Пеев, П., (2017). Методически подходи за въздействие върху скоростна издръжливост при 13-14 годишни футболисти, София, докторат, с. 167.

Peev, P., Tsvetkov, S. and Gadev, M. (2017). Reliability of the field test " $3 \times 50 \mathrm{~m}$ shuttle to determine anaerobic power with football players aged 13-14, Research in $\mathrm{Ki}$ nesiology and Other Related Sciences, Vol. 1, No. 45, pp. 105-108.

Polman, R., Walsh, D., Bloomfield, J. and Nesti, M. (2004). Effective conditioning of female soccer players, Journal of Sports Sciences, February, Vol. 22, No. 2, pp. 191-203.

Rajkumar, S. (2015). Assessment of motor fitness, physical fitness and body composition of women football players at different levels of their participation, American Journal of Sports Science and Medicine, Vol. 3, No. 2, pp. 47-54.

Rohr, G. (1992). Elaboration de batteries de tests d'evaluation sp'ecifique fooballeur, Diplo^me de Brevet d'Etat d'Educateur Degre', Universite' de Bordeaux II (France).

Stølen, T., K. Chamari, C. Castagna, U. Wisløff (2005). Physiology of soccer: An update; Sports Medicine, No. 35, pp. 501-536.

Turner, A., Walker, S., Stembridge, M., Coneyworth, P., Reed, G., Birdsey, L., Barter, P. and Moody, J., (2011). A testing battery for the assessment of fitness in soccer players. Strength \& Conditioning Journal, Vol. 33, No. 5, pp. 29-39.

Vescovi, J.D. and McGuigan, M.R. (2008). Relationships between sprinting, agility, and jump ability in female athletes, Journal of Sports Sciences, January 1, Vol. 26, No. 1, pp. 97-107.

Young, W., Russell, A., Burge, P., Clarke, A., Cormack, S. and Stewart, G., (2008). The use of sprint tests for assessment of speed qualities of elite Australian rules footballers, International journal of sports physiology and performance, Vol. 3, No2, pp.199-206.

\section{Corresponding author:}

Petar Peev

Track and field athletics department National Sports Academy "Vassil Levski" Studentski grad, 21, Acad. Stefan Mladenov str.

Sofia 1700, Bulgaria E-mail: petar.r.peev@gmail.com 